\title{
Desulfosporosinus hippei sp. nov., a mesophilic sulfate-reducing bacterium isolated from permafrost
}

\author{
Correspondence \\ M. Vainshtein \\ vain@ibpm.pushchino.ru
}

\author{
A. Vatsurina, ${ }^{1}$ D. Badrutdinova, ${ }^{2}$ P. Schumann, ${ }^{3}$ S. Spring ${ }^{3}$ \\ and M. Vainshtein ${ }^{1,2}$ \\ ${ }^{1}$ IBPM - Institute of Biochemistry and Physiology of Microorganisms, Russian Academy of \\ Sciences, Prospect Nauki 5, Pushchino, 142290, Moscow region, Russia \\ ${ }^{2}$ Pushchino State University, Prospect Nauki 3, Pushchino, 142290, Moscow region, Russia \\ ${ }^{3} \mathrm{DSMZ}$ - German Collection of Microorganisms and Cell Cultures, Inhoffenstraße 7b, \\ Braunschweig, D-38124, Germany
}

The genus Desulfosporosinus was proposed in 1997 to accommodate the species Desulfotomaculum orientis (Stackebrandt et al., 1997). The genus currently contains four species with validly published names, Desulfosporosinus orientis (Stackebrandt et al., 1997), Desulfosporosinus auripigmenti (Stackebrandt et al., 2003), Desulfosporosinus meridiei (Robertson et al., 2001) and Desulfosporosinus lacus (Ramamoorthy et al., 2006). Desulfosporosinus-like organisms are widespread in different habitats. They exist in environments such as pristine aquifers, municipal drinking water, rice plant roots and permafrost. Members of the genus also inhabit industrially impacted soil and sediments, coal-mining-impacted lakes and radionuclide-contaminated sediments (Vainshtein et al., 2007).

Vainshtein et al. (1994, 1995) isolated the mesophilic, spore-forming, sulfate-reducing strain 343 from ancient permafrost in Russia. At that time, strain 343 was identified as a member of Desulfotomaculum orientis and placed in

The GenBank/EMBL/DDBJ accession number for the $16 \mathrm{~S}$ rRNA gene sequence of strain DSM $8344^{\top}$ is $Y 11571$.

Whole-cell fatty acid profiles of strain DSM $8344^{\top}$ and related type strains are available as supplementary material with the online version of this paper. the German Collection of Microorganisms and Cell Cultures under the number DSM 8344 and in the AllRussian Collection of Microorganisms under the number VKM B-2003. The strain number DSM 8344 is used in this article because all comparative taxonomic studies published so far have referred to this strain as DSM 8344. During the reclassification of Desulfotomaculum orientis as Desulfosporosinus orientis (Stackebrandt et al., 1997), strains Desulfosporosinus (=Desulfotomaculum) orientis DSM $765^{\mathrm{T}}$ and DSM 8344 were compared. They were shown to have a value of only $39 \%$ DNA-DNA reassociation, which clearly indicated the presence of two genomospecies (Stackebrandt et al., 1997). At that time, the lack of distinguishing phenotypic properties prevented the authors from describing a novel species for strain DSM 8344 (Stackebrandt et al., 1997). We describe genetic and phenotypic attributes of DSM 8344 investigated in parallel with the four Desulfosporosinus species that support the recognition of DSM 8344 as representing a distinct and novel species within the genus Desulfosporosinus.

Sampling and isolation procedures were described in detail previously (Vainshtein et al., 1995). In brief, strain DSM 8344 was isolated from 20 to 30000 -year-old permafrost deposits at a depth of $4.2-4.5 \mathrm{~m}$; the temperature in situ was $-5{ }^{\circ} \mathrm{C}$. The strain was isolated from the highest positive 
tubes of a most-probable number (MPN) series. The culture medium used was Postgate B medium (Postgate, 1984) containing $1.0 \mathrm{~g}_{\text {lactate }} \mathrm{l}^{-1}$. Prior to inoculation, the medium was reduced with $10 \mathrm{mg}$ sodium dithionite $\mathrm{l}^{-1}$, added from a freshly prepared anoxic stock solution $(3 \%$ $\mathrm{w} / \mathrm{v})$. Anaerobic techniques were used in all medium preparation and culture manipulations. Unless otherwise indicated, all physiological experiments were performed in triplicate at $30{ }^{\circ} \mathrm{C}$, lasting until cultures reached stationary phase. Uninoculated media served as negative controls. Physiological attributes of strain DSM 8344 were evaluated and compared with those of D. meridiei DSM $13257^{\mathrm{T}}$ (Robertson et al., 2001), D. orientis DSM $765^{\mathrm{T}}$ (Campbell \& Postgate, 1965), D. auripigmenti DSM $13351^{\mathrm{T}}$ (Newman et al., 1997; Stackebrandt et al., 2003) and D. lacus DSM $15449^{\mathrm{T}}$ (Ramamoorthy et al., 2006).

Cell morphology and spore formation were assessed by phase-contrast light microscopy and electron microscopy. Strain DSM 8344 was deemed to be positive for spore formation because cell incubation at $85{ }^{\circ} \mathrm{C}$ for $30 \mathrm{~min}$ was followed by active growth in fresh nutrient medium after reinoculation. Growth was confirmed by both hydrogen sulfide and biomass production.

Temperature and $\mathrm{pH}$ optima were estimated by culturing cells in basal medium amended with sodium lactate and sodium sulfate and monitoring the change in cell number and sulfide production. Cells were counted directly by the method of Yagodka (1975). Direct counting of bacterial cells under the microscope was previously limited in its application to liquid media by the chamber size; the modification of Yagodka (1975) uses direct counting in a drop under a conventional coverglass. The volume is calculated as the product of the area of the counted region (the area of one microscope field of vision multiplied by the number of fields counted) and the depth (calculated with calibration of the microscope focusing system). Sulfide (as $\mathrm{H}_{2} \mathrm{~S}$ ) concentration was estimated by spectrophotometric assay of methylene blue as described by Cline (1969). To determine the temperature optimum, cells were grown at $\mathrm{pH} 7.0$ at 5, 10, 20, 24, 28, 30, 37 and $40{ }^{\circ} \mathrm{C}$. To define the $\mathrm{pH}$ optimum, $20 \mathrm{mM}$ (each) HEPES, PIPES, MES and Tris base buffers were used and the initial medium $\mathrm{pH}$ was set using $1 \mathrm{M} \mathrm{HCl}$ or $1 \mathrm{M} \mathrm{NaOH}$. Cell growth at $\mathrm{pH} 4.0,5.0$, $6.0,6.5,7.0,7.5$ and 8.0 was examined at $28{ }^{\circ} \mathrm{C} . \mathrm{NaCl}$ concentrations up to $30 \%$ were tested to determine the salinity optimum for cell growth at $28{ }^{\circ} \mathrm{C}$ and $\mathrm{pH}$ 7.0.

Strain DSM 8344 was evaluated for its ability to utilize terminal acceptors and to grow using electron donors as indicated in Table 1. To obtain information on chemotaxonomic properties, basal Postgate B medium was used with lactate or sulfate replaced by the appropriate compounds. Anaerobic stock solutions were prepared for each electron acceptor and electron donor and aliquots were added to medium up to $1.0 \mathrm{~g}$ acceptor $\mathrm{l}^{-1}$. Each acceptor was tested using sodium lactate $(10 \mathrm{mM})$ as the carbon source. Each donor was also tested using sulfate
(5 $\mathrm{mM})$ as the terminal electron acceptor. The ability to use electron donors or acceptors was estimated by changes in cell number and sulfide production as described above. The organism was considered positive for utilization of an electron donor or acceptor if two to three doublings occurred after the third passage, with simultaneous production of sulfide. Uninoculated media served as negative controls. Fermentative growth of strain DSM 8344 on pyruvate or lactate (each at $1 \mathrm{~g} \mathrm{l}^{-1}$ ) was evaluated and compared with other members of the genus Desulfosporosinus. Direct cell counting was used to confirm fermentative growth.

Cell-wall preparations were obtained by boiling cells in $20 \%$ (w/v) aqueous trichloroacetic acid solution for $20 \mathrm{~min}$ in accordance with well-known methods. Diaminopimelic acid isomers were detected in cell-wall hydrolysates by TLC on cellulose sheets (Merck) using the solvent system of Rhuland et al. (1955). These methods as well as that used for determination of cellular fatty acid patterns were the same as used for other Desulfosporosinus species (Ramamoorthy et al., 2006).

16S rRNA gene sequence analysis of strain DSM 8344 (GenBank accession no. Y11571) was reported previously (Stackebrandt et al., 1997). The almost-complete 16S rRNA gene sequence of DSM 8344 was aligned with sequences included in the ARB database and those obtained from EMBL (http://www.ebi.ac.uk) using tools implemented in the ARB package (Ludwig et al., 2004). The resulting alignment was inspected visually and potential errors were corrected manually. Evolutionary distances were calculated based on the algorithms of Jukes \& Cantor (1969), using neighbour-joining and parsimony methods of tree reconstruction as implemented in the ARB program package. The databases of $16 \mathrm{~S}$ rRNA gene sequences used in this study, as well as the phylogenetic programs, are available at http:// www.arb-home.de.

Genomic DNA for DNA-DNA hybridization studies was isolated using a French pressure cell and purified by chromatography on hydroxyapatite as described by Cashion et al. (1977). DNA-DNA hybridization was carried out according to the method of De Ley et al. (1970) as modified by Huß et al. (1983), using a Gilford System model 2600 spectrophotometer equipped with a Gilford model 2527-R thermoprogrammer and plotter.

\section{Morphology and physiology}

Cells of strain DSM 8344 were motile, curved rods, 4.5$5.5 \mu \mathrm{m}$ long and 1.0-1.2 $\mu \mathrm{m}$ wide, and formed terminal, round endospores after 2-3 days incubation (Vainshtein et al., 1995). Cells of strain DSM $8344^{\mathrm{T}}$ stained Gramnegative. Flagellation was variable; subpolar flagella were occasionally observed.

Strain DSM 8344 coupled oxidation of lactate to sulfate reduction, conserving energy for growth, and belongs to physiological group I of the sulfate-reducing bacteria, 
Table 1. Distinguishing traits of strain DSM $8344^{\top}$ and related Desulfosporosinus type strains

Data for reference strains are from Ramamoorthy et al. (2006) and Spring \& Rosenzweig (2006). Cells of all strains are curved rods. All strains are positive for the following traits: utilization of sulfate and thiosulfate as electron acceptors and lactate as electron donor and fermentative growth with pyruvate. All strains failed to grow with nitrate as electron acceptor. LL-Diaminopimelic acid is the diagnostic diamino acid in the cell-wall murein of all strains. ND, No data available.

\begin{tabular}{|c|c|c|c|c|c|}
\hline Trait & $\begin{array}{c}\text { D. hippei } \\
\text { DSM } 8344^{\mathrm{T}}\end{array}$ & $\begin{array}{c}\text { D. lacus } \\
\text { DSM } 15449^{\mathrm{T}}\end{array}$ & $\begin{array}{l}\text { D. orientis } \\
\text { DSM } 765^{T}\end{array}$ & $\begin{array}{l}\text { D. meridiei } \\
\text { DSM } 13257^{\mathrm{T}}\end{array}$ & 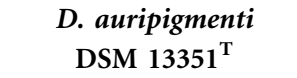 \\
\hline Gram stain & Negative & Negative & Negative & Negative & Positive \\
\hline Morphology & Pairs & Pairs & Pairs & Short chains & Long chains \\
\hline Cell diameter $(\mu \mathrm{m})$ & $1.0-1.2$ & $0.5-0.7$ & $0.7-1.0$ & $0.7-1.1$ & 0.4 \\
\hline Endospores & Round, terminal & $\begin{array}{l}\text { Ellipsoidal, } \\
\text { subterminal }\end{array}$ & $\begin{array}{l}\text { Ellipsoidal, } \\
\text { subterminal }\end{array}$ & $\begin{array}{l}\text { Ellipsoidal, } \\
\text { subterminal }\end{array}$ & $\begin{array}{c}\text { Ellipsoidal, subterminal } \\
\text { to terminal }\end{array}$ \\
\hline Motility & + & + & + & + & - \\
\hline Flagellation type & (Sub)polar & Peritrichous & (Sub)polar or lateral & Lateral & ND \\
\hline \multicolumn{6}{|l|}{ Temperature for growth $\left({ }^{\circ} \mathrm{C}\right)$} \\
\hline Optimum & 28 & 30 & $30-37$ & 28 & $25-30$ \\
\hline Range & $5-37$ & $4-32$ & $<42$ & $10-37$ & ND \\
\hline \multicolumn{6}{|l|}{$\mathrm{pH}$ for growth } \\
\hline Optimum & 7 & ND & 7 & 7 & $6.4-7.0$ \\
\hline Range & $6.5-7.5$ & $6.5-7.5$ & ND & ND & ND \\
\hline $\mathrm{NaCl}$ range $(\%)$ & $<2.0$ & ND & $<5.0$ & $<4.0$ & ND \\
\hline \multicolumn{6}{|c|}{ Electron acceptors in the presence of lactate } \\
\hline Sulfite & - & + & + & + & + \\
\hline Sulfur & - & - & + & + & + \\
\hline $\mathrm{Fe}(\mathrm{III})$ & - & + & - & - & - \\
\hline Fumarate & - & - & + & - & + \\
\hline \multicolumn{6}{|c|}{ Electron donors in the presence of sulfate } \\
\hline Formate & - & + & + & + & + \\
\hline Fumarate & - & - & + & - & - \\
\hline Methanol & - & + & + & + & - \\
\hline Glycerol & - & + & - & + & + \\
\hline Oxidation of $\mathrm{H}_{2}$ (with $\mathrm{CO}_{2}$ ) & - & + & + & + & + \\
\hline Fermentative growth on lactate & - & + & + & + & ND \\
\hline Cytochromes & $b^{*}$ & $c$, traces of $b$ & $b$ & ND & ND \\
\hline DNA G + C content $(\mathrm{mol} \%)$ & $42(\mathrm{HPLC})^{*}$ & 43 (HPLC) & $46\left(T_{\mathrm{m}}\right)$ & $47\left(T_{\mathrm{m}}\right)$ & 42 (HPLC) \\
\hline
\end{tabular}

${ }^{*}$ Data from Vainshtein et al. (1995).

members of which oxidize lactate incompletely to acetate. The strain was able to reduce sulfate over the range of 5$40{ }^{\circ} \mathrm{C}$ with an optimum at $28{ }^{\circ} \mathrm{C}$. All temperature experiments were conducted at $\mathrm{pH}$ 7.0. Although strain DSM 8344 was isolated from a permafrost habitat, the strain grows optimally under mesophilic conditions. Sulfidogenic growth of DSM 8344 was confined to the range $\mathrm{pH} 6.5-7.5$. $\mathrm{NaCl}$ concentrations of $0-0.1 \%$ were optimal for growth of strain DSM 8344. No cell growth was detected with $\mathrm{NaCl}$ concentrations of more than $2 \%$.

Heat-treated cultures of DSM 8344 incubated in fresh medium increased in cell density and accumulated sulfide. This observation can be attributed to the ability of the cells to form high-temperature-resistant endospores.

Electron acceptor and donor preferences for all Desulfosporosinus type strains are summarized in Table 1. All the type strains utilized oxidized inorganic sulfur compounds. However, unlike other Desulfosporosinus strains, DSM 8344 was unable to utilize sulfite as an electron acceptor. Furthermore, DSM 8344 was incapable of using elemental sulfur, fumarate, nitrate or Fe (III) as electron acceptors. Strain DSM 8344 and D. orientis DSM $765^{\mathrm{T}}$ had different electron donor utilization profiles; DSM 8344 was distinct in that it was unable to couple growth to sulfate respiration using formate, fumarate or glycerol as both electron donors and carbon sources. Ethanol and propanol supported poor growth of cultures of DSM 8344. Strain DSM 8344 did not grow autotrophically with hydrogen and either $\mathrm{CO}_{2}$ or acetate as carbon source. No cell growth or sulfide accumulation was observed when cells were cultured on acetate, benzoate, butanol, propionate, malate, succinate, maltose, lactose, sucrose, hexadecane, 2,4-hydrobenzoate, methanol, catechol or choline. Strain DSM 8344 grew fermentatively on pyruvate but not on lactate in the absence of sulfate. 


\section{Chemotaxonomy}

The cellular fatty acid profile for strain DSM 8344 (Supplementary Table S1, available in IJSEM Online) showed that its qualitative composition was similar to those of other representatives of the genus Desulfosporosinus. However, there are quantitative differences, especially in the abundance of 16:0, 16:0 dimethylacetal (dma) and $18: 1$ cis 11 . Fatty acids $16: 1$ cis $9(34.2 \%), 16: 0(9.4 \%)$ and $18: 1$ cis 11 (13.9\%) were predominant in strain DSM 8344. The diagnostic diamino acid of the peptidoglycan of strain DSM 8344 as well of all other type strains of Desulfosporosinus species was LL-diaminopimelic acid (Table 1). Cells of strain DSM 8344 contained $b$-type cytochromes, which is a characteristic of most endosporeforming, sulfate-reducing bacteria studied so far; c-type cytochromes were not observed in this strain.

\section{Phylogeny and comparative genomics}

A parsimony tree was constructed (Fig. 1) based on $16 \mathrm{~S}$ rRNA gene sequences; the tree demonstrates that strain DSM 8344 and other members of the genus Desulfosporosinus group together to form a cluster with $97 \%$ bootstrap support. Sequence similarities based on the comparison of almost-complete $16 \mathrm{~S}$ rRNA gene sequences indicate that strain DSM 8344 is most closely related to $D$. meridiei DSM $13257^{\mathrm{T}}$ (97.9\% 16S rRNA gene similarity), whereas the similarity value to $D$. orientis DSM $765^{\mathrm{T}}$ is only $96.2 \%$. Trees were also reconstructed using the neighbourjoining method, but displayed no significant differences in branching order from the parsimony tree.

Currently DNA-DNA hybridization values between two strains of less than $70 \%$ are considered to warrant recognition of strains as members of separate species (Wayne et al., 1987; Stackebrandt \& Goebel, 1994). Previously, DNA-DNA hybridization experiments have revealed that strain DSM 8344 shows only $39 \%$ reassociation with $D$. orientis DSM $765^{\mathrm{T}}$ (Stackebrandt et al., 1997), thereby excluding its assignment to this species as originally proposed by Vainshtein et al. (1995). In this study, the ratio of DNA-DNA binding with the closest phylogenetic relative, D. meridiei DSM $13257^{\mathrm{T}}$, was determined and was found to be $57 \%$.

Ribotype patterns determined previously also clearly indicate a distinct position of strain DSM 8344 separate from all other type strains of the genus Desulfosporosinus (Stackebrandt et al., 2003; Spring \& Rosenzweig, 2006).

The DNA G+C content of strain DSM 8344 was $42.1 \mathrm{~mol} \%$.

Strain DSM 8344 is also distinguished phenotypically from other members of the genus by its fatty acid profile and its inability to use sulfite or iron as an electron acceptor or to grow by oxidation of hydrogen (Table 1). This last trait is a novel feature amongst Desulfosporosinus species, meaning that an emendation of the genus description is necessary. Consequently, phylogenetic and chemotaxonomic data indicate that strain DSM 8344 represents a novel species of Desulfosporosinus, Desulfosporosinus hippei sp. nov.

\section{Emended description of the genus Desulfosporosinus Stackebrandt et al. 1997 emend. Stackebrandt et al. 2003}

The emended description of Stackebrandt et al. (2003) is further modified as follows. The genus also includes species that do not oxidize hydrogen with $\mathrm{CO}_{2}$ or acetate as carbon source.

\section{Description of Desulfosporosinus hippei sp. nov.}

Desulfosporosinus hippei (hip'pe.i. N.L. gen. n. hippei of Hippe, named after Hans H. Hippe, of the DSMZ, for his numerous contributions to the cultivation and taxonomy of sulfate-reducing bacteria).

Cells are curved rods, stain Gram-negative and have subpolar flagella. Individual cells are 4.5-5.5 $\mu \mathrm{m}$ long and $1.0-1.2 \mu \mathrm{m}$ wide. They produce heat-resistant, terminal, round endospores. Utilizes sulfate and thiosulfate as terminal electron acceptors in the presence of lactate.

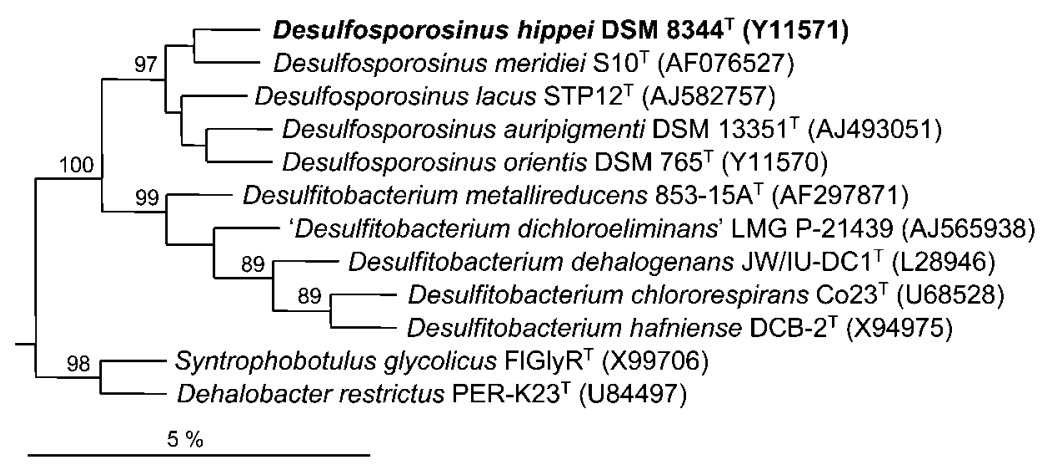

Fig. 1. Phylogenetic tree based on an alignment of almost-complete 16S rRNA gene sequences showing the affiliation of strain DSM $8344^{\top}$ to the genus Desulfosporosinus. The tree was reconstructed using the program DNAPARS implemented in the PHYLIP package of the ARB software (version 03_08_22). Only bootstrap values above $80 \%$ (as percentages of 1000 resamplings) are shown. The root is defined using sequences of unidentified strains of Peptococcus niger (X55797) and Desulfotomaculum nigrificans (AB026550) (not shown). Bar, 5\% estimated sequence divergence. 
Sulfite, elemental sulfur, fumarate, nitrate and $\mathrm{Fe}(\mathrm{III})$ are not used as electron acceptors. In the presence of sulfate, ethanol and propanol are utilized slightly as electron donors and carbon sources. Cannot use acetate, benzoate, butanol, propionate, malate, succinate, maltose, lactose, sucrose, hexadecane, 2,4-hydrobenzoate, methanol or choline as electron donors or carbon sources. Cells are capable of fermentative growth using pyruvate but not lactate as an energy source in the absence of any electron acceptor. The temperature and $\mathrm{pH}$ ranges for growth are $5-37^{\circ} \mathrm{C}$ and $\mathrm{pH} 6.5-7.5$. Cells grow well at $\mathrm{NaCl}$ concentrations up to $1 \mathrm{~g} \mathrm{l}^{-1}$. NaCl inhibits growth at concentrations above $20 \mathrm{~g} \mathrm{l}^{-1}$. Possesses $b$-type cytochromes. The diagnostic diamino acid of the peptidoglycan is LL-diaminopimelic acid. Major fatty acids $(>5 \%)$ are (as percentages of the total) $16: 1$ cis 9 (34.2\%), 16:0 (9.4\%), $18: 1$ cis $11 \quad(13.9 \%)$ and $18: 1$ cis 9 (9.7\%). The G+C content of the DNA of the type strain is $42.1 \mathrm{~mol} \%$.

The type strain is strain $343^{\mathrm{T}}\left(=\mathrm{DSM} 8344^{\mathrm{T}}=\mathrm{VKM} \mathrm{B}-\right.$ $\left.2003^{\mathrm{T}}\right)$, isolated from ancient (20-30 thousand years old) permafrost deposits in Kolyma region, Siberia, Russia.

\section{Acknowledgements}

The authors thank Dr V. Akimov (IBPM) for his assistance and critical commentary.

\section{References}

Campbell, L. L. \& Postgate, J. R. (1965). Classification of the sporeforming sulfate-reducing bacteria. Bacteriol Rev 29, 359-363.

Cashion, P., Holder-Franklin, M. A., McCully, J. \& Franklin, M. (1977). A rapid method for the base ratio determination of bacterial DNA. Anal Biochem 81, 461-466.

Cline, J. D. (1969). Spectrophotometric determination of hydrogen sulfide in natural waters. Limnol Oceanogr 14, 454-458.

De Ley, J., Cattoir, H. \& Reynaerts, A. (1970). The quantitative measurement of DNA hybridization from renaturation rates. Eur $J$ Biochem 12, 133-142.

Huß, V. A. R., Festl, H. \& Schleifer, K. H. (1983). Studies on the spectrophotometric determination of DNA hybridization from renaturation rates. Syst Appl Microbiol 4, 184-192.

Jukes, T. H. \& Cantor, C. R. (1969). Evolution of protein molecules. In Mammalian Protein Metabolism, vol. 3, pp. 21-132. Edited by H. N. Munro. New York: Academic Press.

Ludwig, W., Strunk, O., Westram, R., Richter, L., Meier, H., Yadhukumar, Buchner, A., Lai, T., Steppi, S. \& other authors (2004). ARB: a software environment for sequence data. Nucleic Acids Res 32, 1363-1371.

Newman, D. K., Kennedy, E. K., Coates, J. D., Ahmann, D., Ellis, D. J., Lovley, D. R. \& Morel, F. M. (1997). Dissimilatory arsenate and sulfate reduction in Desulfotomaculum auripigmentum sp. nov. Arch Microbiol 168, 380-388.

Postgate J. R. (1984). The Sulfate-Reducing Bacteria, 2nd edn. Cambridge: Cambridge University Press.

Rainey, F. A., Ward-Rainey, N., Kroppenstedt, R. M. \& Stackebrandt, E. (1996). The genus Nocardiopsis represents a phylogenetically coherent taxon and a distinct actinomycete lineage: proposal of Nocardiopsaceae fam. nov. Int J Syst Bacteriol 46, 1088-1092.

Ramamoorthy, S., Sass, H., Langner, H., Schumann, P., Kroppenstedt, R. M., Spring, S., Overmann, J. \& Rosenzweig, R. F. (2006). Desulfosporosinus lacus sp. nov., a sulfate-reducing bacterium isolated from pristine freshwater lake sediments. Int J Syst Evol Microbiol 56, 2729-2736.

Rhuland, L. E., Work, E., Denman, R. F. \& Hoare, D. S. (1955). The behavior of the isomers of $\alpha, \varepsilon$-diaminopimelic acid on paper chromatograms. J Am Chem Soc 77, 4844-4846.

Robertson, W. J., Bowman, J. P., Franzmann, P. D. \& Mee, B. J. (2001). Desulfosporosinus meridiei sp. nov., a spore-forming sulfatereducing bacterium isolated from gasolene-contaminated groundwater. Int J Syst Evol Microbiol 51, 133-140.

Spring, S. \& Rosenzweig, R. F. (2006). The genera Desulfitobacterium and Desulfosporosinus: taxonomy. In The Prokaryotes: a Handbook on the Biology of Bacteria, 3rd edn, vol. 4, pp. 771-786. Edited by M. Dworkin, S. Falkow, E. Rosenberg, K. H. Schleifer \& E. Stackebrandt. New York: Springer.

Stackebrandt, E. \& Goebel, B. M. (1994). Taxonomic note: a place for DNA-DNA reassociation and 16S rRNA sequence analysis in the present species definition in bacteriology. Int J Syst Bacteriol 44, 846-849.

Stackebrandt, E., Spröer, C., Rainey, F. A., Burghardt, J., Päuker, O. \& Hippe, H. (1997). Phylogenetic analysis of the genus Desulfotomaculum: evidence for the misclassification of Desulfotomaculum guttoideum and description of Desulfotomaculum orientis as Desulfosporosinus orientis gen. nov., comb. nov. Int J Syst Bacteriol 47, 1134-1139.

Stackebrandt, E., Schumann, P., Schüler, E. \& Hippe, H. (2003). Reclassification of Desulfotomaculum auripigmentum as Desulfosporosinus auripigmenti corrig., comb. nov. Int J Syst Evol Microbiol 53, 1439-1443.

Vainshtein, M., Gogotova, G. \& Hippe, H. (1994). A sulfate-reducing bacterium from the permafrost. In Viable Microorganisms in Permafrost, pp. 68-74. Edited by D. Gilichinsky. Pushchino: Russian Academy of Science Pushchino Research Center.

Vainshtein, M. B., Gogotova, G. I. \& Hippe, H. (1995). A sulfatereducing bacterium from permafrost. Microbiology (English translation of Mikrobiologiia) 64, 436-439.

Vainshtein, M. B., Alfyorov, V. A. \& Vatsurina, A. V. (2007). Manual on Water Microbiology and Biogeochemistry. Tula, Russia: Tula State University (in Russian).

Wayne, L. G., Brenner, D. J., Colwell, R. R., Grimont, P. A. D., Kandler, O., Krichevsky, M. I., Moore, L. H., Moore, W. E. C., Murray, R. G. E. \& other authors (1987). International Committee on Systematic Bacteriology. Report of the ad hoc committee on reconciliation of approaches to bacterial systematics. Int J Syst Bacteriol 37, 463-464.

Yagodka, S. N. (1975). A new variant of the method of direct counting of bacteria in water. Mikrobiologiia 44, 169-170 (in Russian). 